\title{
PENGARUH KOMPENSASI FINANSIAL, LINGKUNGAN KERJA NON FISIK, DAN KOMITMEN ORGANISASIONAL TERHADAP SEMANGAT KERJA KARYAWAN
}

\author{
I Gede Widya Darmawan ${ }^{1}$ \\ I Made Artha Wibawa ${ }^{2}$ \\ ${ }^{1}$ Fakultas Ekonomi dan Bisnis Universitas Udayana (Unud), Bali, Indonesia \\ e-mail: gedecikde@gmail.com
}

\begin{abstract}
ABSTRAK
Tujuan penelitian ini adalah untuk mengetahui pengaruh kompensasi finansial, lingkungan kerja non fisik, dan komitmen organisasional terhadap semangat kerja karyawan Penelitian ini dilakukan di KSP. Tat Twam Asi Denpasar, jumlah sampel yang diambil sebanyak 30 orang karyawan, dengan metode sampel jenuh/ sensus. Pengumpulan data dilakukan melalui wawancara dan kuesioner. Teknik analisis menggunakan teknik analysis regresi linear berganda. Pada observasi awal ditemukan bahwa pada KSP. Tat Twam Asi Denpasar ini memiliki masalah terkait dengan semangat kerja karyawannya. Hal ini terlihat dari tingkat absensi karyawan yang tinggi. Berdasarkan hasil analisis ditemukan bahwa kompensasi finansial, lingkungan kerja non fisik, dan komitmen organisasional secara simultan maupun parsial berpengaruh positif terhadap semangat kerja karyawan. Hal ini menunjukan bahwa semakin tinggi kompensasi dan komitmen orgnisasional maka semangat kerja karyawan akan semakin tinggi. Dalam upaya meningkatkan semangat kerja dari karyawan KSP. Tat Twam Asi sebaiknya perusahaan lebih memperhatikan indikator yang nilai rata-ratanya berada dibawah nilai rata-rata variabel.
\end{abstract}

Kata kunci : kompensasi finansial, lingkungan kerja non fisik, komitmen organisasional, semangat kerja karyawan.

\begin{abstract}
The purpose of this study was to study comparative financial research, non-physical work environment, and organizational commitment to morale. This research was conducted at KSP. Tat Twam Asi Denpasar, the number of samples taken was 30 employees, with the method of saturated samples / census. Data collection is done through interviews and questionnaires. The analysis technique uses multiple linear regression analysis techniques. At the initial observation found in KSP. Tat Twam Asi Denpasar has a problem related to the employee morale. This can be seen from the high employee absentee level. Based on the results of the analysis found that financial compensation, non-physical work environment, and organizational commitment simultaneously or partially positive commitment to employee morale. This shows that the higher compensation and organizational commitment, the higher employee morale will be. KSP. Tat Twam, the approved company considers the average value indicators that are approved by the average value variable.

Keywords: financial compensation, non physical work environment, commitment organizational, employee morale.
\end{abstract}




\section{PENDAHULUAN}

Perusahaan merupakan suatu perkumpulan dua orang atau lebih yang memiliki kesamaan prinsip dan saling berinteraksi dalam menjalankan aktivitasnya untuk mencapai tujuan bersama. Keberhasilan dalam mengelola perusahaan tidaklah lepas dari adanya campur tangan sumber daya manusia karena sumber daya manusia merupakan modal serta asset utama yang dimiliki suatu perusahaan untuk mencapai suatu tujuan secara efektif dan efesien, dengan demikian dapat dikatakan bahwa ini sangat berkaitan erat dengan manajemen sumber daya manusia.

Menurut Hasibuan (2014:10) manajemen sumber daya manusia adalah ilmu dan seni mengatur hubungan dan peranan tenaga kerja agar efektif dan efesien membantu terwujudnya tujuan perusahaan, karyawan, dan masyarakat. Pentingnya peran sumber daya manusia didalam perusahaan, selain oleh karena kemampuan dan juga skill yang dimiliki, semangat kerja dari sumber daya manusia tersebut haruslah berbanding lurus. Peran sumber daya manusia dalam organisasi adalah modal dasar dimana semangat kerja karyawan sangat menentukan maju dan mundurnya suatu organisasi (Rimawathi, 2008). Dalam upaya meningkatkan semangat kerja karyawan, salah satu caranya adalah dengan mengurangi tingkat kesalahan yang dilakukan dalam melaksanakan pekerjaannya (Lelyana, 2008). Semangat kerja merupakan sikap individu dan kelompok terhadap seluruh lingkungan kerja dan kerjasama dengan orang lain secara maksimal sesuai dengan kepentingan yang paling baik perusahaan (MacRobert et $a l ., 2008)$. Berdasarkan pendapat tersebut bahwa pentingnya suatu semangat kerja akan turut membantu tercapainya tujuan dari suatu perusahaan tak terkecuali terhadap lembaga keuangan non bank salah satunya adalah koperasi.

Dalam undang-undang RI no 25 pada tahun 1992 pasal 1 tentang perkoperasian dikatakan bahwa koperasi adalah badan usaha yang beranggotakan orang-seorang atau badan hukum koperasi dengan melandaskan kegiatannya berdasarkan prinsip koperasi sekaligus sebagai gerakan ekonomi rakyat yang berdasar atas asas kekeluargaan, serta pada pasal 4 yang memuat tentang fungsi dan peran koperasi yaitu, 1) membangun dan mengembangkan potensi dan kemampuan ekonomi anggota pada khususnya dan pada masyarakat pada umumnya untuk meningkatkan kesejahteraan ekonomi dan sosialnya, 2) berperan secara aktif dalam upaya mempertinggi kualitas kehidupan manusia dan masyarakat, 3) memperkokoh perekonomian rakyat sebagai dasar kekuatan dan ketahanan perekonomian nasional dengan koperasi sebagai sokogurunya, 4) berusaha untuk mewujudkan dan mengembangkan perekonomian nasional yang merupakan usaha bersama berdasar atas asas kekeluargaan dan demokrasi ekonomi.

Pada era globalisasi ini kebutuhan masyarakat akan kebereadaan lembaga keuangan non bank seperti koperasi ini semakin tinggi, terbukti dengan melesatnya pertumbuhan (revitalisasi) koperasi di kabupaten dan kota seluruh Indonesia. Seperti pada Kota Denpasar, berdasarkan data pada Dinas Koperasi dan UMKM bahwa jumlah koperasi baik koperasi fungsional, koperasi jasa, koperasi produsen dan koperasi simpan pinjam di Kota Denpasar sampai pada 
tahun 2016 adalah sebanyak 1.004 koperasi yang aktif. Meningkatnya pertumbuhan koperasi di Denpasar tidak lah lepas dari adanya pola pikir masyarakat yang menginginkan adanya pembangunan ekonomi kerakyatan melalui program pemberdayaan masyarakat yang menitikberatkan pada pengembangan ekonomi masyarakat dengan harapan dapat meningkatkan taraf hidup masyarakat.

Koperasi Simpan Pinjam (KSP) Tat Twam Asi adalah salah satu koperasi yang berada di kota Denpasar, koperasi yang berdiri sejak 6 februari 1999 dan didirikan atas dasar kesepakatan bersama prajuru dan warga adat $\mathrm{Br}$. Tengah Sesetan ini merupakan suatu unit ekonomi pekraman dengan besar harapan, keberadannya mampu membangun perekonomian seluruh anggotanya demi kesejahteraan ekonomi yang lebih baik. Berdasarkan observasi awal dan wawancara tidak tersturuktur terhadap 10 orang karyawan KSP. Tat Twam Asi dapat disimpulkan bahwa terdapat masalah terkait dengan semangat kerja karyawan yang dapat dilihat dari tidak harmonisnya hubungan manusia antar karyawan, komunikasi antar karyawan masih kurang efektif, rendahnya motivasi karyawan, kurangnya perlindungan terhadap kesehatan dan keselamatan terhadap karyawan, serta kurangnya peran pemimpin dalam mengayomi karyawan bawahannya.

Selain indikasi tersebut, salah satu indikasi menurunnya semangat kerja karyawan lainnya adalah ketidakhadiran karyawan yang tinggi (Nitisemito, 2012). Data mengenai tingkat absensi kerja karyawan pada KSP. Tat Twam Asi Denpasar dapat terlihat dari Tabel 1 sebagai berikut.

Tabel 1.

Tingkat Absensi Kerja Pada KSP. Tat Twan Asi Denpasar Periode Januari - Desember Tahun 2017

\begin{tabular}{|c|c|c|c|c|c|c|}
\hline Bulan & $\begin{array}{c}\text { Jumlah } \\
\text { Tenaga } \\
\text { kerja } \\
\text { (orang) }\end{array}$ & $\begin{array}{c}\text { Jumlah } \\
\text { Hari } \\
\text { Kerja } \\
\text { (Hari) }\end{array}$ & $\begin{array}{c}\text { Jumlah } \\
\text { hari kerja } \\
\text { seharusnya } \\
\text { (hari) }\end{array}$ & $\begin{array}{c}\text { Jumlah } \\
\text { Absensi } \\
\text { (Hari) }\end{array}$ & $\begin{array}{c}\text { Jumlah } \\
\text { hari kerja } \\
\text { Senyatanya } \\
\text { (Hari) }\end{array}$ & $\begin{array}{l}\text { Presentasi } \\
\text { absensi } \\
(\%)\end{array}$ \\
\hline $\mathbf{A}$ & B & $\mathbf{C}$ & $\mathrm{D}=\mathrm{BxC}$ & $€$ & $\mathbf{F}=\mathbf{D}-\mathbf{E}$ & $G=E: D \times 100 \%$ \\
\hline Januari & 30 & 26 & 780 & 23 & 757 & 2,95 \\
\hline Februari & 30 & 24 & 720 & 22 & 698 & 3,06 \\
\hline Maret & 30 & 25 & 750 & 26 & 724 & 3,47 \\
\hline April & 30 & 26 & 780 & 23 & 757 & 2,95 \\
\hline Mei & 30 & 25 & 750 & 23 & 727 & 3,07 \\
\hline Juni & 30 & 26 & 780 & 25 & 755 & 3,21 \\
\hline Juli & 30 & 26 & 780 & 26 & 754 & 3,33 \\
\hline Agustus & 30 & 25 & 750 & 22 & 728 & 2,93 \\
\hline September & 30 & 25 & 750 & 23 & 727 & 3,07 \\
\hline Oktober & 30 & 26 & 780 & 26 & 754 & 3,33 \\
\hline November & 30 & 24 & 720 & 22 & 698 & 3,06 \\
\hline Desember & 30 & 25 & 750 & 23 & 727 & 3,07 \\
\hline \multicolumn{2}{|c|}{$\begin{array}{c}\text { Jumlah } \\
\text { Rata-rata }\end{array}$} & 303 & 9090 & 284 & 8806 & $\begin{array}{c}37,48 \\
3,12\end{array}$ \\
\hline
\end{tabular}

Sumber : KSP. Tat Twan Asi Denpasar, 2018 
Pada Tabel 1. dapat dijelaskan bahwa absensi karyawan KSP. Tat Twan Asi Denpasar Januari-Desember 2017 cenderung berfluktuasi dimana rata - rata tingkat absensi karyawan sebesar 3,12 persen. Apabila dilihat dari jumlah karyawan, maka tingkat absensi tergolong tinggi karena jumlah karyawan pada KSP. Tat Twan Asi Denpasar adalah sebanyak 30 orang. Menurut Mudiarta, (2014 ) mengemukakan bahwa rata-rata tingkat absensi 2-3 persen perbulan masih dianggap baik, absensi 3 persen ke atas menunjukkan tingkatan kerja yang buruk di dalam suatu perusahaan.

Menurut Hariyanti (2005: 155) semangat kerja adalah kesediaan perasaan yang memungkinkan seseorang bekerja untuk menghasilkan kerja lebih banyak dan lebih baik. Semangat kerja sebagai kemampuan sekelompok orang untuk bekerja sama dengan giat dan konsekuen dalam mengejar tujuan bersama (Leighten, 2006 : 130), sehingga karena kurangnya semangat kerja karyawan KSP. Tat Twam Asi yang merupakan pioneer utama dalam perusahaan dalam menggembangkan keberhasilannya, menyebabkan tidak tercapainya tujuan dari perusahaan ini. Rendahnya semangat kerja karyawan dapat disebabkan oleh beberapa faktor, salah satunya adalah kompensasi finansial (Diana dan Subudi, 2013). Peningkatkan semangat kerja karyawan juga dapat ditentukan oleh kompensasi yang diterima setiap karyawannya (Pravasta dan Sintaasih, 2014). Kompensasi adalah balas jasa yang bersifat material maupun nonmaterial yang diberikan berdasarkan kebijaksanaan yang bertujuan untuk memperbaiki kondisi fisik dan mental karyawan (Hasibuan, 2007: 185).

Faktor lain yang mempengaruhi semangat kerja karyawan adalah lingkungan kerja non fisik (Sari, 2014). Lingkungan kerja non fisik adalah semua keadaan yang terjadi yang berkaitan dengan hubungan kerja baik dengan atasan maupun dengan rekan kerja ataupun dengan bawahan. Organisasi perlu menciptakan dan memelihara lingkungan kerja yang baik karena lingkungan kerja yang baik akan dapat menimbulkan suasana kerja yang dapat membuat karyawan bersemangat untuk bekerja lebih giat dan lebih baik.

Selain, beberapa faktor diatas adapun faktor lain yang mempengaruhi semangat kerja ialah komitmen organisasional (Triyana dan Wibawa, 2014). Komitmen organisasional adalah dorongan dari dalam individu untuk berbuat sesuatu agar dapat menunjang keberhasilan organisasi sesuai dengan tujuan dan lebih mengutamakan kepentingan organisasi dibandingkan dengan kepentingan sendiri (Weiner dalam Coryanata, 2004). Karyawan dengan komitmen organisasional yang tinggi dapat diharapkan akan memperlihatkan semangat kerja yang optimal. Berdasarkan uraian latar belakang masalah tersebut maka penelitian ini akan menganalisis tentang pengaruh kompensasi finansial, lingkungan kerja non fisik, komitmen organisasional terhadap semangat kerja karyawan.

Berdasarkan uraian latar belakang di atas, rumusan masalah dalam penelitian ini adalah Bagaimana pengaruh kompensasi finansial, lingkungan kerja non fisik, komitmen organisasional secara simultan dan parsial terhadap semangat kerja karyawan ?. Adapun tujuan dalam penelitian ini adalah Untuk mengetahui pengaruh signifikan antara kompensasi finansial, lingkungan kerja non fisik, komitmen organisasional secara simultan dan parsial terhadap semangat kerja karyawan. 
Grand theory yang digunakan dalam penelitian ini yaitu menggunakan Teori Harapan (Expectancy Theory). Teori ini menyatakan bahwa kekuatan yang membuat seseorang untuk bekerja giat dalam mengerjakan pekerjaannya tergantung dari hubungan timbal balik antara apa yang diinginkan dan dibutuhkan dari hasil pekerjaan itu (H.Vroom, 1964). Vroom (1990) mengemukakan bahwa orang-orang akan termotivasi untuk melakukan hal-hal tertentu guna mencapai tujuan apabila mereka yakin bahwa tindakan mereka akan mengarah pada pencapaian tujuan tersebut. Tiga asumsi pokok teori harapan ini, yaitu : 1) Setiap individu percaya bahwa bila ia berprilaku dengan cara tertentu, ia akan memperoleh hal tertentu (outcome expectancy); 2) Setiap hasil mempunyai nilai, atau daya tarik bagi orang tertentu (valence); 3) Setiap hasil berkaitan dengan suatu persepsi mengenai seberapa sulit mencapai hasil tersebut (effort expectancy).

Expectancy merupakan salah satu penggerak yang mendasari seseorang untuk melakukan suatu tindakan. Karena dengan adanya usaha yang keras tersebut, maka hasil yang didapat akan sesuai dengan tujuan. Dalam teori ini disebutkan bahwa seseorang akan memaksimalkan sesuatu yang menguntungkan dan meminimalkan sesuatu yang merugikan bagi pencapaian tujuan akhirnya.

Secara sistematis, kerangka konseptual dalam penelitian ini disajikan pada Gambar 1 sebagai berikut.

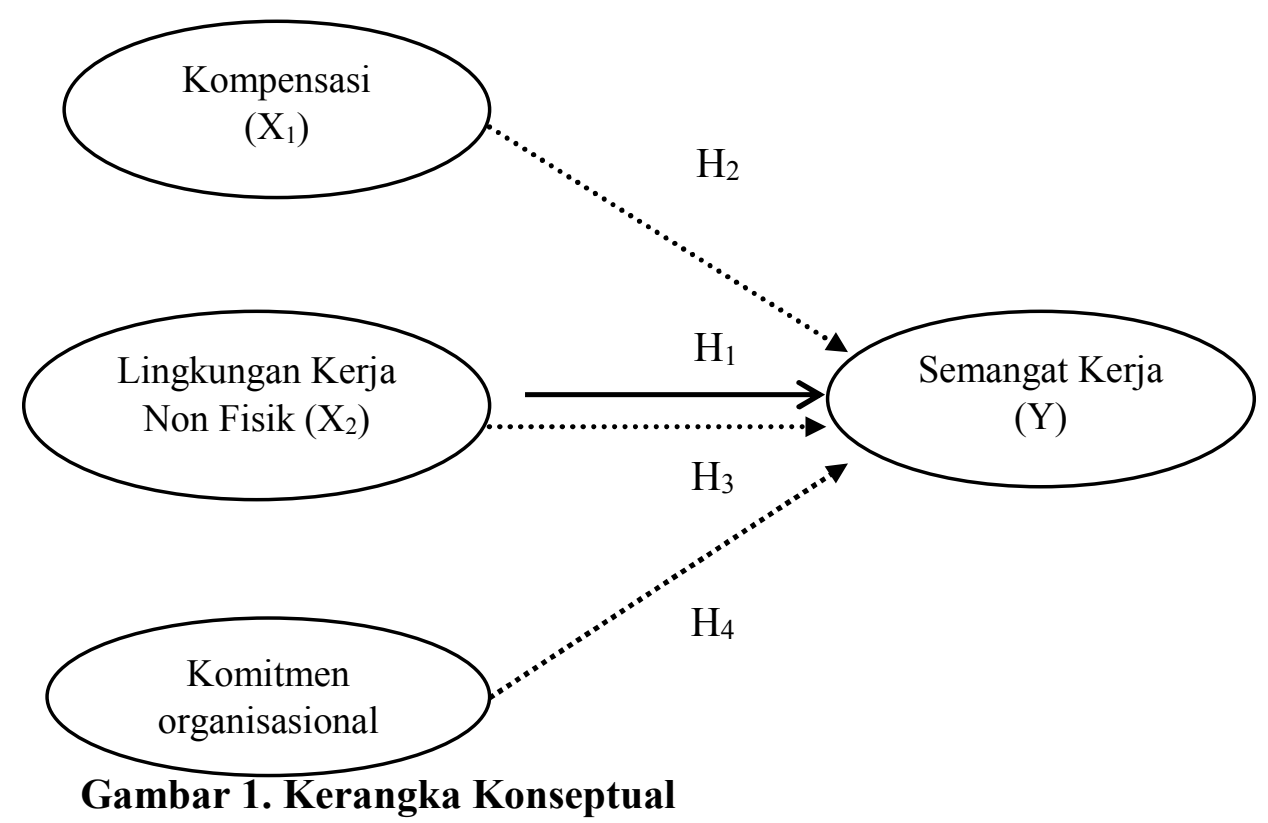

Keterangan :

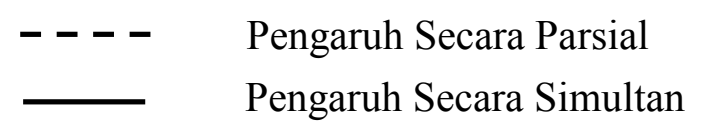


Kompensasi finansial adalah segala sesuatu yang diterima para karyawan sebagai balas jasa untuk kerja mereka (Handoko, 2001: 155).Hasil penelitian Yasa dan Wibawa (2015) menyimpulkan bahwa kompensasi finansial berpengaruh signifikan dan positif terhadap semangat kerja. Penelitian Febriani dan Subudi (2015) juga menyimpulkan bahwa kompensasi finansial berpengaruh positif dan signifikan terhadap semangat kerja karyawan, dimana dengan pemberian kompensasi yang sesuai maka akan meningkatkan semangat kerja karyawan.

Lingkungan kerja merupakan segala sesuatu yang ada disekitar para pekerja yang dapat mempengaruhi dirinya dalam menjalankan tugas-tugas yang dibebankan. Lingkungan kerja non fisik adalah semua keadaan yang terjadi yang berkaitan dengan hubungan kerja, baik hubungan dengan atasan maupun hubungan dengan sesama rekan kerja, ataupun hubungan dengan bawahan (Sedarmayanti, 2009: 26). Hasil penelitian Rahayu dan Ruzikna (2011) menyimpulkan bahwa lingkungan kerja baik fisik maupun non fisik berpengaruh positif dan signifikan terhadap semangat kerja karyawan. Penelitian Sari, dkk (2015) menyimpulkan bahwa terdapat pengaruh positif dan signifikan antara lingkungan kerja non fisik terhadap semangat kerja karyawan.

Tingkat komitmen perusahaan yang baik terhadap karyawan, maupun antara karyawan terhadap perusahaan sangat diperlukan karena melalui komitmenkomitmen tersebut akan tercipta iklim kerja yang professional Menurut (Ghozali, 2006: 193). Penelitian Ursa (2007) menyimpulkan bahwa komitmen organisasional berpengaruh secara parsial terhadap semangat kerja seseorang untuk bekerja. Hasil penelitian Triyana dan Wibawa (2014) menyimpulkan bahwa komitmen organisasional berpengaruh secara parsial dan simultan terhadap semangat kerja karyawan. Berdasarkan landasan teori dan hasil penelitian diatas, maka dikemukakan hipotesis sebagai berikut.

$\mathrm{H}_{1}$ : Kompensasi finansial, lingkungan kerja non fisik, dan komitmen organisasional berpengaruh positif dan signifikan terhadap semangat kerja karyawan.

Pemberian kompensasi finansial ditujukan agar karyawan bekerja lebih baik dan mengarah kepada pekerjaan-pekerjaan yang lebih produktif (Martoyo, 2008:116). Kompensasi finansial dapat diberikan melalui tunjangan-tunjangan seperti gaji, tunjangan transportasi, tunjangan makan dan tunjangan hari raya. Kompensasi finansial digunakan secara benar disebabkan kompensasi finansial bagian dari usaha dimana semakin tinggi usaha yang dikerahkan maka semakin besar kompensasi finansial yang diterima. (McKnight et al., 2008).

Penelitian Pravasta dan Sintaasih (2014) menyimpulkan bahwa kompensasi finansial berpengaruh positif dan signifikan terhadap semangat kerja. Diana dan Subudi (2014) dalam penelitiannya menyimpulkan bahwa kompensasi finansial berpengaruh positif terhadap semangat kerja. Dari hasil penelitian sebelumnya, dapat disimpulkan bahwa semakin tinggi kompensasi finansial yang diberikan maka semakin tinggi pula semangat kerja karyawan. Berdasarkan landasan teori dan hasil penelitian diatas, maka dikemukakan hipotesis sebagai berikut.

$\mathrm{H}_{2}$ : Kompensasi finansial berpengaruh positif dan signifikan terhadap semangat kerja karyawan. 
Lingkungan kerja adalah segala sesuatu yang ada di lingkungan sekitar para pekerja dan yang dapat mempengaruhi dirinya dalam menjalankan tugas-tugas yang dibebankan kepadanya (Nitisemito, 2008:183). Hasil penelitian Anisaa (2015) menyatakan bahwa lingkungan kerja berpengaruh positif dan sedang terhadap semangat kerja karyawan, dimana semakin baik lingkungan kerja maka semakin tinggi semangat kerja karyawan.

Marhamah (2016) menyimpulkan bahwa lingkungan kerja non fisik berpengaruh positif dan signifikan terhadap semangat kerja. Srivastava (2008) mengatakan bahwa di antara berbagai komponen. Lingkungan kerja, kondisi kerja, kesejahteraan, hubungan-hubungan antar pribadi, dan kepercayaan sebagian besar harapan untuk perilaku pekerjaan karyawan dan menyangkut efektivitas organisasi. Hal ini menunjukan bahwa lingkungan kerja non fisik yang kondusif, selaras, dan serasi akan meningkatkan suasana pekerjaan yang baik. Berdasarkan landasan teori dan hasil penelitian diatas, maka dikemukakan hipotesis yaitu.

$\mathrm{H}_{3} \quad$ : Lingkungan kerja non fisik berpengaruh positif dan signifikan terhadap semangat kerja karyawan.

Komitmen organisasional menurut Rivai (2012:67) dapat diartikan sebagai identifikasi, loyalitas, dan keterlibatan yang dinyatakan oleh karyawan oleh organisasi atau unit dari organisasi. Komitmen organisasional sebagai derajat seberapa jauh karyawan mengidentifikasi dirinya dengan organisasi dan keterlibatannya dalam organisasi tertentu (Windy dan Gunasti, 2012). Penelitian Triyana (2014) menyimpulkan bahwa komitmen organisasional berpengaruh secara parsial terhadap semangat kerja. Windy (2012) mengatakan bahwa komitmen organisasional melalui uji parsial berpengaruh terhadap semangat kerja karyawan. Resi (2011) menemukan dalam penelitiannya bahwa komitmen organisasional secara parsial berpengaruh terhadap semangat kerja karyawan. Dari pemahaman diatas dapat ditarik hipotesis sebagai berikut.

$\mathrm{H}_{4} \quad$ : Komitmen organisasional berpengaruh positif dan signifikan terhadap semangat kerja karyawan.

\section{METODE PENELITIAN}

Dalam penelitian ini berbentuk asosiatif menggunakan pendekatan kuantitatif. Tujuan Penelitian ini menggunakan desain penelitian asosiatif yaitu untuk mengetaui hubungan antara kompensasi finansial, lingkungan kerja non fisik dan komitmen organisasional terhadap semangat kerja karyawan. Pendekatan kuantitatif yang digunakan dalam penelitian ini untuk meneliti data yang bersifat statistik serta menguji suatu hipotesis. Penelitian ini dilakukan di KSP Tat Twam Asi yang beralamat di Jalan Raya Sesetan No.113A Kelurahan Sesetan Denpasar, Lokasi ini dipilih karena adanya permasalahan yang terkait dengan semangat kerja karyawan.

Jumlah populasi dalam penelitian ini adalah 30 orang, maka penelitian ini menggunakan teknik sampel jenuh atau sensus dimana sebanyak 30 orang karyawan dijadikan responden. Metode pengumpulan data pada penelitian ini menggunakan metode survey dengan teknik pengumpulan data dengan melakukan wawancara dan menggunakan kuesioner (angket). Kuesioner yang disebarkan 
berupa daftar pernyataan kepada responden mengenai kompensasi finansial, lingkungan kerja non fisik, dan komitmen organisasional terhadap semangat kerja karyawan. Hasil jawaban tersebut kemudian diukur menggunakan skala likert, yaitu pilihan jawaban responden diberi nilai dengan skala 5 poin. Teknik analisis data penelitian ini menggunakan teknik analisis linier berganda. Pengujian selanjutnya yaitu, uji asumsi klasik, analisis deskriptif dan uji t.

Analisis linier berganda ini digunakan untuk mengetahui seberapa besar pengaruh variabel bebas yaitu Kompensasi finansial $\left(\mathrm{X}_{1}\right)$, Lingkungan Kerja Non Fisik $\left(\mathrm{X}_{2}\right)$, dan Komitmen organisasional $\left(\mathrm{X}_{3}\right)$ terhadap variabel terikatnya yaitu Semangat Kerja (Y).

Bentuk persamaan regresi linier berganda adalah sebagai berikut. (Ghozali, 2005), sebagai berikut.

$\mathrm{Y}=\mathrm{a}+\mathrm{b}_{1} \cdot \mathrm{X}_{1}+\mathrm{b}_{2} \cdot \mathrm{X}_{2}+\mathrm{b}_{3} \cdot \mathrm{X}_{3}+\mathrm{ei}$

Keterangan:

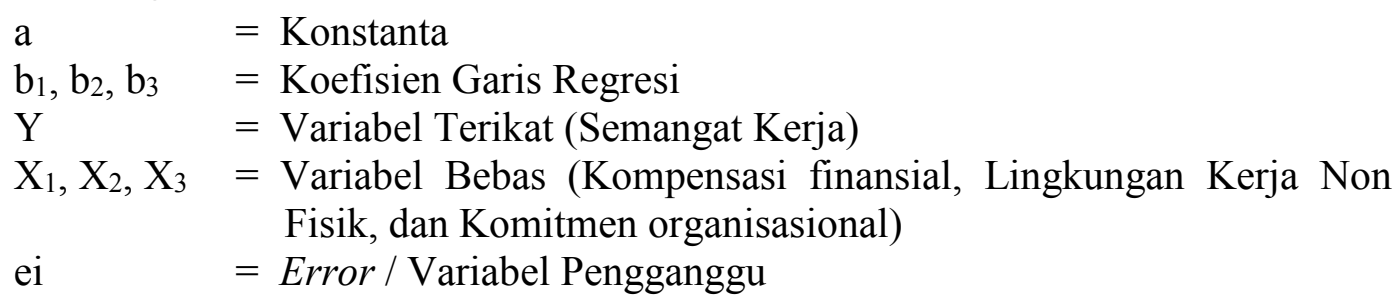

\section{HASIL DAN PEMBAHASAN}

Jumlah responden yang digunakan dalam penelitian ini, yaitu sebanyak 30 responden yang merupakan seluruh karyawan KSP Tat Twan Asi Sesetan Denpasar. Data mengenai karakteristik responden disajikan pada Tabel 2. sebagai berikut.

Berdasarkan Tabel 2, dapat terlihat bahwa responden dalam penelitian ini didominasi oleh perempuan yaitu sebanyak 60 persen, sementara responden berjenis kelamin laki-laki sebesar 40 persen. Hasil karakterisitik usia responden dalam kuesioner penelitian memperlihatkan bahwa responden dengan usia terbanyak adalah responden dengan usia 36-45 tahun dibandingkan dengan kelompok usia lainnya dengan persentase 53,3 persen. Sementara itu, responden dengan bekerja selama 5-10 tahun adalah yang paling banyak di antara kelompok lama bekerja lainnya dengan persentase sebesar 50 persen.

Statistik deskriptif bertujuan untuk memberikan informasi mengenai karakteristik variabel - variabel penelitian yaitu jumlah amatan nilai minimum, nilai maksimum, nilai mean, dan standar deviasi (Sugiyono, 2017:206). Jumlah responden yang dijadikan sampel data penelitian pada KSP Tat Twam Asi Sesetan Denpasar adalah sebanyak 30 karyawan dengan peniliaian mengenai kompensasi finansial, lingkungan kerja non fisik, komitmen organisasional dan semangat kerja karyawan, dengan masing-masing jawaban diberikan skor 1-5. Dengan rumus interval kelas adalah sebagai berikut. 
Interval kelas $=\frac{\text { Nilai tertinggi-Nilai terendah }}{\text { Jumlah kelas }}$

Interval kelas $=5-1 / 5=0,80$

Tabel 2.

Karakteristik Responden Penelitian

\begin{tabular}{|c|c|c|c|}
\hline & Karakteristik & Frekuensi & Persentase (\%) \\
\hline \multirow[t]{4}{*}{1} & Jenis Kelamin & & \\
\hline & - Laki-laki & 12 & 40 \\
\hline & - Perempuan & 18 & 60 \\
\hline & Total & 30 & 100 \\
\hline \multirow[t]{5}{*}{2} & Usia & & \\
\hline & - 25-35 Tahun & 8 & 26,7 \\
\hline & - $36-45$ Tahun & 16 & 53,3 \\
\hline & - $\quad 46-55$ Tahun & 6 & 20 \\
\hline & Total & 30 & 100 \\
\hline \multirow[t]{7}{*}{3} & Jabatan & & \\
\hline & - Manager Operasional & 1 & 3,3 \\
\hline & - Accounting & 2 & 6,7 \\
\hline & - Funding & 12 & 40 \\
\hline & - Teller & 6 & 20 \\
\hline & - Kredit & 9 & 30 \\
\hline & Total & 30 & 100 \\
\hline \multirow[t]{5}{*}{4} & Lama Bekerja & & \\
\hline & - $\quad<5$ Tahun & 10 & 33,3 \\
\hline & - 5-10 Tahun & 15 & 50 \\
\hline & - $>10$ Tahun & 5 & 16,7 \\
\hline & Total & 30 & 100 \\
\hline
\end{tabular}

Sumber : Data diolah, 2018

Penelitian kualitatif dipergunakan skor rata-rata jawaban responden dengan kriteria dan kategori penilaian jawaban kuisioner seperti Tabel 3 sebagai berikut.

Tabel 3.

Kriteria dan Kategori Penilaian Jawaban Kuisioner Kompensasi Finansial, Lingkungan Kerja Non Fisik, dan Komitmen Organisasional Terhadap Semangat Kerja Karyawan KSP. Tat Twam Asi Denpasar

\begin{tabular}{|c|c|c|}
\hline \multirow[b]{2}{*}{ Batas-batas Klasifikasi (Kriteria) } & \multicolumn{2}{|c|}{ Variabel Penelitian } \\
\hline & $\begin{array}{c}\text { Lingkungan Kerja Non } \\
\text { Fisik }\left(\mathrm{X}_{2}\right)\end{array}$ & $\begin{array}{c}\text { Semangat Kerja }(Y), \\
\text { Kompenasi }\left(\mathrm{X}_{1}\right), \\
\text { Komitmen } \\
\text { Organisasional }\left(\mathrm{X}_{3}\right)\end{array}$ \\
\hline $1,00-1,80$ & Sangat Tidak Baik & Sangat rendah \\
\hline $1,81-2,60$ & Tidak Baik & Rendah \\
\hline $2,61-3,40$ & Kurang Baik & Cukup \\
\hline $3,41-4,20$ & Baik & Tinggi \\
\hline $4,21-5,00$ & Sangat Baik & Sangat Tinggi \\
\hline
\end{tabular}

Sumber : data diolah, 
Analisis deskriptif disajikan untuk memberikan informasi mengenai distribusi variabel-variabel penelitian yang dapat dilihat pada tabel-tabel sebagai berikut ini.

Tabel 4.

Hasil Penilaian Responden atas Variabel Semangat Kerja Karyawan pada KSP. Tat Twam Asi Denpasar

\begin{tabular}{|c|c|c|c|c|c|c|c|}
\hline \multirow{2}{*}{ No } & \multirow{2}{*}{ Pernyataan } & \multicolumn{5}{|c|}{ Jawaban } & \multirow{2}{*}{$\begin{array}{l}\text { Rata-rata } \\
\text { Skor }\end{array}$} \\
\hline & & STS & TS & $\mathbf{N}$ & $\mathbf{S}$ & SS & \\
\hline 1 & $\begin{array}{l}\text { Saya merasa cocok terhadap } \\
\text { teman sekerja di perusahaan. }\left(\mathrm{Y}_{1}\right)\end{array}$ & 0 & 0 & 0 & 15 & 15 & 4,50 \\
\hline 2 & $\begin{array}{l}\text { Saya dan rekan kerja } \\
\text { berkomunikasi dengan baik. }\left(\mathrm{Y}_{2}\right)\end{array}$ & 0 & 0 & 2 & 20 & 8 & 4,20 \\
\hline 3 & $\begin{array}{l}\text { Saya berusaha datang ke tempat } \\
\text { kerja lebih awal dari pada waktu } \\
\text { yang telah ditentukan. }\left(\mathrm{Y}_{3}\right)\end{array}$ & 0 & 0 & 2 & 22 & 6 & 4,13 \\
\hline 4 & $\begin{array}{l}\text { Saya bekerja dengan rasa aman } \\
\text { pada perusahaan ini. }\left(\mathrm{Y}_{4}\right)\end{array}$ & 0 & 0 & 5 & 21 & 4 & 3,97 \\
\hline 5 & $\begin{array}{l}\text { Pemimpin selalu mengawasi } \\
\text { pekerjaan saya. }\left(\mathrm{Y}_{5}\right)\end{array}$ & 0 & 0 & 5 & 22 & 3 & 3,93 \\
\hline \multicolumn{7}{|c|}{$\begin{array}{c}\text { Jumlah } \\
\text { Rata-rata skor }\end{array}$} & $\begin{array}{c}20,73 \\
4,15\end{array}$ \\
\hline
\end{tabular}

Sumber : Data diolah, 2018

Pada Tabel 4. variabel semangat kerja dinilai tinggi oleh responden secara keseluruhan dan memiliki nilai rata-rata sebesar 4,15,. Nilai rata-rata yang tinggi itu disumbang oleh dua indikator, yaitu indikator hubungan manusia $\left(\mathrm{Y}_{1}\right)$ sebesar 4,50 dan indikator komunikasi $\left(\mathrm{Y}_{2}\right)$ sebesar 4,20. Hasil ini dapat berarti bahwa pihak perusahaan telah memupuk rasa memiliki serta komunikasi diantara para karyawan sehingga tercipta hubungan yang harmonis sehingga dapat meningkatkan semangat kerja karyawan di KSP. Tat Twam Asi Sesetan Denpasar.

Adapun penilaian karyawan KSP. Tat Twam Asi Denpasar mengenai kompensasi finansial dapat dilihat pada Tabel 5 sebagai berikut.

Pada Tabel 5, menunjukkan bahwa variabel kompensasi finansial dinilai tinggi oleh responden secara keseluruhan dan memiliki nilai rata-rata sebesar 4,13. Nilai rata-rata yang tinggi itu disumbang oleh dua indikator, yaitu indikator gaji $\left(\mathrm{X}_{1.1}\right)$ sebesar 4,60 dan indikator insentif $\left(\mathrm{X}_{1.2}\right)$ sebesar 4,27. Hal ini menunjukan bahwa pihak perusahaan telah memberikan gaji serta insentif yang layak dan sudah sesuai dengan UMK Kota Denpasar. Kompensasi sangat penting hal nya untuk membuat karyawan bekerja lebih baik dan mengarah kepada pekerjaan-pekerjaan yang lebih produktif.

Adapun penilaian karyawan KSP. Tat Twam Asi Denpasar mengenai kompensasi finansial dapat dilihat pada Tabel 6 sebagai berikut. 
Tabel 5.

Hasil Penilaian Responden atas Variabel Kompensasi Finansial pada KSP. Tat Twam Asi Denpasar

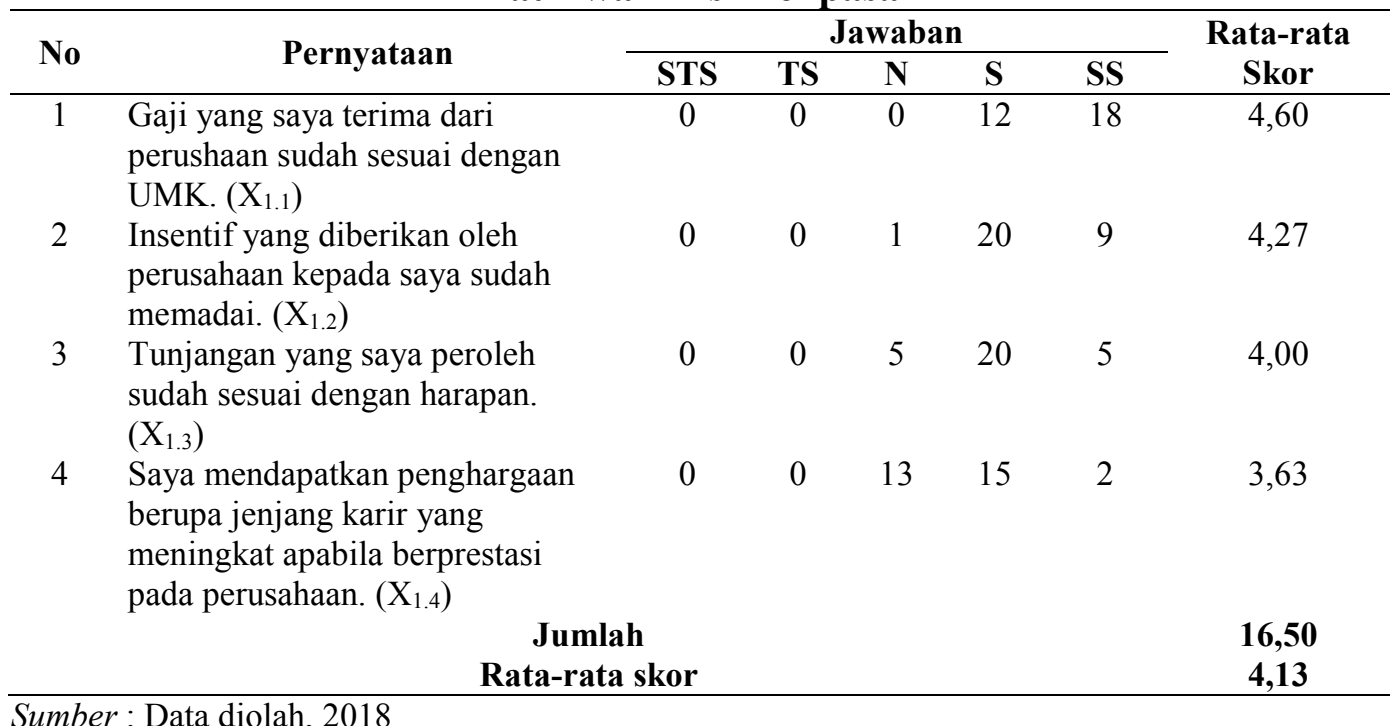

Tabel 6.

Hasil Penilaian Responden atas Variabel Lingkungan Kerja Non Fisik pada KSP. Tat Twam Asi Denpasar

\begin{tabular}{|c|c|c|c|c|c|c|c|}
\hline \multirow{2}{*}{ No } & \multirow{2}{*}{ Pernyataan } & \multicolumn{5}{|c|}{ Jawaban } & \multirow{2}{*}{ Rata-rata Skor } \\
\hline & & $\begin{array}{l}\text { STS } \\
\end{array}$ & TS & $\mathbf{N}$ & $\mathbf{S}$ & SS & \\
\hline 1 & $\begin{array}{l}\text { Saya bekerja sesuai dengan } \\
\text { prosedur kerja yang telah } \\
\text { diatur secara berurutan. } \\
\left(\mathrm{X}_{2.1}\right)\end{array}$ & 0 & 0 & 20 & 10 & 0 & 3,33 \\
\hline 2 & $\begin{array}{l}\text { Saya bekerja sesuai dengan } \\
\text { standar kerja yang diberikan } \\
\text { agar mencapai tujuan } \\
\text { perusahaan. }\left(\mathrm{X}_{2.2}\right)\end{array}$ & 0 & 5 & 25 & 0 & 0 & 2,83 \\
\hline 3 & $\begin{array}{l}\text { Perusahaan menyusun tugas } \\
\text { karyawan agar pekerjaan } \\
\text { dapat dikerjakan secara adil. } \\
\left(\mathrm{X}_{2.3}\right)\end{array}$ & 0 & 12 & 18 & 0 & 0 & 2,60 \\
\hline 4 & $\begin{array}{l}\text { Saya mampu melaksanakan } \\
\text { pekerjaan berdasarkan } \\
\text { instruksi dari atasan. }\left(\mathrm{X}_{2.4}\right)\end{array}$ & 0 & 25 & 5 & 0 & 0 & 2,17 \\
\hline 5 & $\begin{array}{l}\text { Perusahaan memberikan } \\
\text { penghargaan untuk } \\
\text { mengenali prestasi } \\
\text { karyawan. }\left(\mathrm{X}_{2.5}\right)\end{array}$ & 0 & 27 & 3 & 0 & 0 & 2,10 \\
\hline \multirow[t]{2}{*}{6} & $\begin{array}{l}\text { Hubungan antar karyawan } \\
\text { pada perusahaan berjalan } \\
\text { harmonis. }\left(\mathrm{X}_{2.6}\right)\end{array}$ & 0 & 27 & 3 & 0 & 0 & 2,10 \\
\hline & \multicolumn{3}{|c|}{$\begin{array}{l}\text { Jumlah } \\
\text { Rata-rata skor }\end{array}$} & & & & $\begin{array}{c}15,13 \\
2,52\end{array}$ \\
\hline
\end{tabular}


Pada Tabel 6, menunjukan bahwa deskripsi jawaban responden terhadap variabel lingkungan kerja non fisik dinilai tidak baik oleh responden secara keseluruhan dan memiliki nilai rata-rata sebesar 2,52. Nilai indikator variabel yang nilai rata-ratanya diatas nilai rata-rata variabel, yaitu indikator prosedur kerja $\left(\mathrm{X}_{2.1}\right)$ sebesar 3,33, selanjutnya indikator standar kerja $\left(\mathrm{X}_{2.2}\right)$ sebesar 2,83, dan indikator pertanggung jawaban supervisor $\left(\mathrm{X}_{2.3}\right)$ sebesar 2,60. Hal ini menunjukan bahwa KSP. Tat Twam Asi belum mampu untuk menciptakan hubungan kerja yang baik, baik antara atasan dengan bawahan, sesama rekan kerja maupun dengan bawahannya.

Tabel 7.

Hasil Penilaian Responden atas Variabel Komitmen Organisasional pada KSP. Tat Twam Asi Denpasar

\begin{tabular}{|c|c|c|c|c|c|c|c|}
\hline \multirow{2}{*}{ No } & \multirow{2}{*}{ Pernyataan } & \multicolumn{5}{|c|}{ Jawaban } & \multirow{2}{*}{ Rata-rata Skor } \\
\hline & & STS & TS & $\mathbf{N}$ & $\mathbf{S}$ & SS & \\
\hline 1 & $\begin{array}{l}\text { Saya senang untuk } \\
\text { menghabiskan karir di } \\
\text { organisasi ini. }\left(\mathrm{X}_{3.1}\right)\end{array}$ & 0 & 0 & 1 & 15 & 14 & 4,43 \\
\hline 2 & $\begin{array}{l}\text { Saya merasa menjadi bagian } \\
\text { keluarga di organisasi ini. } \\
\left(\mathrm{X}_{3.2}\right)\end{array}$ & 0 & 0 & 2 & 12 & 16 & 4,47 \\
\hline 3 & $\begin{array}{l}\text { Saya sulit untuk } \\
\text { meninggalkan organisasi ini. } \\
\left(\mathrm{X}_{3.3}\right)\end{array}$ & 0 & 0 & 1 & 20 & 9 & 4,27 \\
\hline 4 & $\begin{array}{l}\text { Kehidupan saya akan } \\
\text { terganggu bila meninggalkan } \\
\text { organisasi ini. }\left(\mathrm{X}_{3.4}\right)\end{array}$ & 0 & 0 & 3 & 21 & 6 & 4,10 \\
\hline 5 & $\begin{array}{l}\text { Saya memiliki } \\
\text { tanggungjawab untuk tetap } \\
\text { bertahan dalam organisasi } \\
\text { ini. }\left(\mathrm{X}_{3.5}\right)\end{array}$ & 0 & 0 & 6 & 20 & 4 & 3,93 \\
\hline \multirow[t]{2}{*}{6} & $\begin{array}{l}\text { Berpindah ke organisasi lain } \\
\text { sangatlah tidak etis bagi } \\
\text { saya. }\left(\mathrm{X}_{3.6}\right)\end{array}$ & 0 & 0 & 9 & 19 & 2 & 3,77 \\
\hline & \multicolumn{3}{|c|}{$\begin{array}{c}\text { Jumlah } \\
\text { Rata-rata skor }\end{array}$} & & & & $\begin{array}{r}24,97 \\
4,16\end{array}$ \\
\hline
\end{tabular}

Sumber : Data diolah, 2018

Berdasarkan Tabel 7. terlihat bahwa variabel komitmen organisasional dinilai tinggi oleh responden secara keseluruhan dan memiliki nilai rata-rata sebesar 4,18 . Nilai rata-rata yang tinggi itu disumbang oleh tiga indicator, yaitu indikator $\left(\mathrm{X}_{3.1}\right)$ sebesar 4,43, indikator $\left(\mathrm{X}_{3.2}\right)$ sebesar 4,60, dan indikator $\left(\mathrm{X}_{3.3}\right)$ sebesar 4,27. Hal ini menunjukan bahwa para karyawan KSP. Tat Twam Asi telah memiliki sikap tegas dan berpegang teguh untuk selalu memprioritaskan masalah maupun tujuan organisasinya.

Analisis regresi linear berganda bertujuan untuk mengetahui ketergantungan suatu variabel terikat dengan satu atau lebih variabel bebas. Analisis ini juga dapat menduga arah dari hubungan tersebut serta mengukur derajat keeratan hubungan antara satu variabel terikat dengan satu variabel bebas. 
Adapun hasil analisis regresi dengan menggunakan program SPSS dapat dilihat pada Tabel 8. sebagai berikut.

Tabel 8.

Hasil Analisis Regresi Linear Berganda

\begin{tabular}{|c|c|c|c|c|}
\hline \multicolumn{2}{|c|}{ Variabel terikat } & Variabel Bebas & Koefisien Regresi & Sig. \\
\hline \multicolumn{2}{|c|}{ Semangat Kerja Karyawan } & Kompensasi Finansial & 0,462 & 0,001 \\
\hline & & Komminen urganisasional & 0,304 & 0,007 \\
\hline Constant & $=0,460$ & & & \\
\hline Adj. R Square & $=0,637$ & & & \\
\hline R Square & $=0,675$ & & & \\
\hline F Ratio & $=17,987$ & & & \\
\hline Sig. & $=0,000$ & & & \\
\hline
\end{tabular}

Berdasarkan Tabel 8. dapat ditulis persamaan regresi linear berganda sebagai berikut.

$\mathrm{Y}=0,460+0,462 \cdot \mathrm{X}_{1}+0,334 \cdot \mathrm{X}_{2}+0,304 \cdot \mathrm{X}_{3}+\mathrm{ei}$

Keterangan:

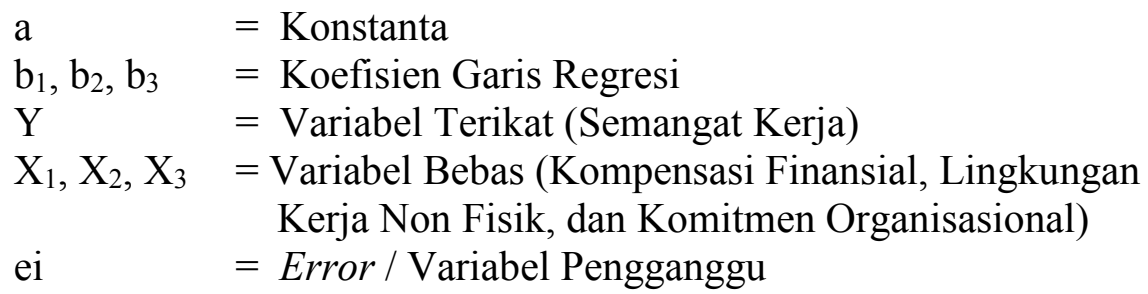

Dilihat dari hasil analisis regresi linear berganda pada Tabel 8 diatas, maka dapat disimpulkan bahwa konstanta adalah sebesar 0,460 yang artinya jika kompensasi finansial, lingkungan kerja non fisik, komitmen organisasional dianggap konstan bernilai nol, maka semangat kerja akan naik sebesar 0,460 satuan.

Terdapat juga pengaruh positif kompensasi finansial terhadap semangat kerja. Hal ini berarti, bahwa apabila kompensasi finansial meningkat maka semangat kerja akan meningkat. Terdapat juga pengaruh positif lingkungan kerja non fisik terhadap semangat kerja. Hal ini berarti, bahwa apabila lingkungan kerja non fisik meningkat maka semangat kerja akan meningkat. Terdapat juga pengaruh positif komitmen organisasional terhadap semangat kerja. Hal ini berarti, bahwa apabila komitmen organisasional meningkat maka semangat kerja akan meningkat.

Uji asumsi klasik bertujuan untuk menguji apakah variabel yang digunakan bebas dari adanya penyimpangan. Model regresi yang baik adalah model regresi yang terbebas dari masalah multikolinieritas, heteroskedasitas, serta masalah 
normalitas data. Hasil uji asumsi klasik yang diolah dengan menggunakan SPSS disajikan sebagai berikut.

Uji normalitas dilakukan untuk menguji apakah pada residual dari model regresi yang telah dibuat berdistribusi normal atau tidak. Kriteria yang digunakan uji ini adalah dengan membandingkan antara tingkat signifikansi yang didapat dengan tingkat alpha yang digunakan yaitu 5\% $(0,05)$. Jika nilai signifikansinya lebih besar dari alpha 0,05, maka distribusi data dinyatakan memenuhi asumsi normalitas. Hasil uji normalitas dapat dilihat pada Tabel 9 sebagai berikut.

Tabel 9.

Hasil Uji Normalitas

\begin{tabular}{lccc}
\hline & Statistik & Df & Sig \\
\hline $\begin{array}{l}\text { Unstandardized } \\
\text { Residual }\end{array}$ & 0.086 & 30 & $.200^{*}$ \\
\hline
\end{tabular}

Sumber : Data diolah, 2018

Berdasarkan Tabel 9. dapat dilihat bahwa nilai signifikan adalah sebesar 0,200. Hasil tersebut mengindikasikan bahwa model persamaan regresi tersebut berdistribusi normal karena nilai signifikan sebesar 0,200 lebih besar dari nilai alpha 0,05 .

Uji multikolinieritas menguji apakah model regresi ditemukan adanya korelasi antar variabel bebas. Adanya multikolinieritas dapat dilihat dari nilai tolerance atau variance inflation factor $(V I F)$. Jika nilai tolerance lebih dari 0,10 atau sama dengan nilai $V I F>10$. Maka dikatakan tidak ada multikolinearitas.

Tabel 10.

Hasil Uji Multikolinearitas

\begin{tabular}{lcc}
\hline \multicolumn{1}{c}{ Variabel } & Tolerance & VIF \\
\hline Kompensasi Finansial & 0,827 & 1,209 \\
Lingkungan Kerja Non Fisik & 0,837 & 1,194 \\
Komitmen Organisasional & 0,707 & 1,415 \\
\hline Sumber $:$ Data diolah, 2018 & &
\end{tabular}

Pada Tabel 10. dapat dilihat bahwa dari nilai tolerance dan variance inflation factor (VIF) dari variabel kompensasi finansial, lingkungan kerja non fisik, dan komitmen organisasional. Nilai tersebut menunjukan bahwa nilai tolerance untuk setiap variabel kurang dari 0,10 dan nilai variance inflation factor (VIF) lebih besar dari 10 yang berarti model persamaan regresi bebas dari multikolinearitas.

Uji heterokedastisitas bertujuan untuk mengetahui apakah dalam model terjadi ketidaksamaan varian dari residual satu pengamatan ke pengamatan lain yang dilakukan dengan uji Glejser. Model dikatakan tidak mengandung gejala heterokedastisitas jika tabel coefficients menghasilkan nilai signifikansi lebih besar dari alpha 0,05 .

\section{Tabel 11.}


Hasil Uji Heterokedastisitas

\begin{tabular}{lccccc}
\hline \multirow{2}{*}{ Model } & \multicolumn{2}{c}{$\begin{array}{c}\text { Unstandardized } \\
\text { Coefficients }\end{array}$} & $\begin{array}{c}\text { Standardized } \\
\text { Coefficients }\end{array}$ & \multirow{2}{*}{ T } & Sig. \\
\cline { 2 - 4 } & $\mathbf{B}$ & $\begin{array}{c}\text { Std. } \\
\text { Error }\end{array}$ & Beta & & \\
\hline (Constant) & -1.151 & 1.551 & & -0.742 & 0.465 \\
Kompensasi Finansial & 0.080 & 0.067 & 0.234 & 1.184 & 0.465 \\
Lingkungan Kerja Non Fisik & 0.163 & 0.080 & 0.400 & 2.035 & 0.247 \\
Komitmen Organisasional & -0.071 & 0.057 & -0.266 & -1.246 & 0.052 \\
\hline Sumber : Data diolah, 2018 & & & & &
\end{tabular}

Pada Tabel 11. dapat dilihat bahwa nilai signifikansi dari variabel kompensasi finansial, lingkungan kerja non fisik, dan komitmen organisasional Seluruh nilai masing-masing variabel tersebut lebih besar dari alpha 0,05 yang berarti bahwa model yang dibuat tidak mengandung gejala heterokedastisitas.

Nilai R Square model (Uji koefisien determinasi) pada tabel 8 hasil uji analisis regresi linier berganda sebesar 0,675 artinya 67,5 persen semangat kerja karyawan dipengaruhi oleh kompensasi finansial, lingkungan kerja non fisik dan komitmen organisasional. sedangkan 32,5 persen dijelaskan oleh variabel lain diluar model.

Hasil uji $\mathrm{F}$ ( $F$ test ) pada Tabel 8 menunjukkan bahwa nilai signifikansi $\mathrm{P}$ value sebesar 0,000 yang lebih kecil dari $\alpha=0,05$, ini berarti model yang digunakan pada penelitian ini layak digunakan dan mampu memprediksi atau menjelaskan fenomena semangat kerja karyawan di KSP. Tat Twam Asi Denpasar.

Pada Tabel 8. hasil uji analisis regresi linier berganda, terbukti bahwa kompensasi finansial, lingkungan kerja non fisik, dan komitmen organisasional berpengaruh positif dan signifikan terhadap semangat kerja karyawan. Hasil penelitian ini mengembangkan penelitian yang dilakukan oleh Yasa dan Wibawa (2015); Febriani dan Subudi (2015) yang menyatakan bahwa kompensasi finansial berpengaruh positif dang signifikan terhadap semangat kerja karyawan. Selanjutnya penelitian yang dilakukan oleh Rahayu dan Ruzikna (2011) menyimpulkan bahwa lingkungan kerja non fisik maupun fisik berpengaruh positif dan signifikan terhadap semangat kerja karyawan, hal yang sama juga disimpulkan oleh Sari, dkk (2015) bahwa lingkungan kerja non fisik berpengaruh positif dan signifikan terhadap semangat kerja karyawan. Serta pada penelitian oleh Triyana dan Wibawa (2014) menyimpulkan bahwa komitmen organisasional berpengaruh secara positif secara parsial dan simultan terhadap semangat kerja karyawan.

Berdasarkan hasil uji analisis regresi linier berganda pada Tabel 8 . menunjukkan bahwa pengaruh kompensasi finansial terhadap semangat kerja karyawan diperoleh nilai signifikansi sebesar 0,001 $<0.05$ (significant) dengan nilai koefisien regresi sebesar 0,462 sehingga $\mathrm{H}_{0}$ ditolak dan $\mathrm{H}_{1}$ diterima. Hal ini berarti bahwa kompensasi finansial secara parsial berpengaruh positif dan signifikan terhadap semangat kerja karyawan KSP. Tat Twam Asi Denpasar. Peneliti menemukan bahwa pada variabel kompensasi finansial, indikator gaji memiliki nilai rata-rata paling tinggi dari keseluruhan nilai rata-rata indikator 
lainnya yang ada pada variabel ini. Hal ini memiliki arti bahwa karyawan KSP. Tat Twam Asi Denpasar mengharapkan bahwa gaji atau suatu balas jasa yang akan diterimanya dapat sesuai dengan kontibusi yang diberikannya terhadap perusahaan.

Hasil penelitian ini mengembangkan hasil penelitian yang dilakukan oleh Pravasta dan Sintaasih (2014) menyimpulkan bahwa kompensasi finansial secara parsial berpengaruh secara positif dan signifikan terhadap semangat kerja karyawan. Serta sejalan dengan penelitian oleh Diana dan Subudi (2014) yang menyatakan menyimpulkan bahwa kompensasi finansial berpengaruh secara positif dan signifikan terhadap semangat kerja karyawan.

Berdasarkan hasil uji analisis regresi linier berganda pada Tabel 8 menunjukkan bahwa pengaruh lingkungan kerja non fisik terhadap semangat kerja karyawan diperoleh nilai signifikansi sebesar 0,031<0.05 (significant) dengan nilai koefisien regresi sebesar 0,334 sehingga $\mathrm{H}_{0}$ ditolak dan $\mathrm{H}_{1}$ diterima. Hal ini membuktikan bahwa lingkungan kerja non fisik secara parsial berpengaruh positif dan signifikan terhadap semangat kerja karyawan. Pada hasil penilaian responden terhadap variabel lingkungan kerja non fisik, peneliti menemukan bahwa indikator prosedur kerja memiliki nilai rata-rata paling tinggi dari keseluruhan nilai rata-rata indikator lainnya yang ada pada variabel ini. Hal ini memiliki arti bahwa seluruh rangakaian tata pelaksanaan kerja atau urutan kerja yang diatur oleh perusahaan akan menentukan tinggi atau rendahnya semangat kerja dari karyawan KSP. Tat Twam Asi Denpasar.

Hasil penelitian ini mengembangkan hasil penelitian yang dilakukan oleh Anisaa (2015) yang menyimpulkan bahwa lingkungan kerja non fisik berpengaruh secara positif dan sedang terhadap semangat kerja karyawan. Hal ini juga mendukung penelitian oleh Marhamah (2016) yang menyatakan bahwa lingkungan kerja non fisik berpengaruh secara positif dan signifikan terhadap semangat kerja karyawan. Lingkungan kerja non fisik yang kondusif, selaras, dan serasi akan meningkatkan suasan pekerjaan yang baik (Srivastava, 2008).

Berdasarkan hasil uji analisis regresi linier berganda pada Tabel 8 menunjukkan bahwa pengaruh komitmen organisasional terhadap semangat kerja karyawan diperoleh nilai signifikansi sebesar 0,007 0.05 (significant) dengan nilai koefisien regresi sebesar 0,304 sehingga $\mathrm{H}_{0}$ ditolak dan $\mathrm{H}_{1}$ diterima. Hal ini membuktikan bahwa komitmen orgaisasional secara parsial berpengaruh positif dan signifikan terhadap semangat kerja karyawan. Pada hasil penilaian responden terhadap variabel komitmen orgaisasional, peneliti menemukan bahwa indikator merasa menjadi bagian dari keluarga di organisasi memiliki nilai rata-rata paling tinggi dari keseluruhan nilai rata-rata indikator lainnya yang ada pada variabel ini. Hal ini memiliki arti bahwa ikatan emosional para karyawan KSP. Tat Twam Asi Denpasar akan menimbulkan rasa keinginannya bertahan dan mengabdikan dirinya kepada perusahaan. Hal ini tentu akan berdampak terhadap semangat kerja karyawan KSP. Tat Twam Asi Denpasar

Hasil penelitian ini mengembangkan dengan penelitian yang dilakukan oleh Triyana dan Wibawa (2014) yang menyimpulkan bahwa komitmen organisasional berpengaruh positif secara parsial terhadap semangat kerja karyawan, hal ini juga didukung oleh penelitian yang dilakukan oleh Windy (2012); Resi (2011) yang 
menyatakan bahwa komitmen organisasional berpengaruh secara parsial terhadap semangat kerja karyawan.

\section{SIMPULAN}

Berdasarkan hasil analisis dan pembahasan tentang pengaruh kompensasi finansial, lingkungan kerja non fisik, dan komitmen organisasional terhadap semangat kerja karyawan pada KSP. Tat Twam Asi Denpasar, maka dapat ditarik kesimpulan bahwa Kompensasi finansial, lingkungan kerja non fisik, dan komitmen organisasional secara parsial maupun simultan memiliki pengaruh positif dan signifikan terhadap semangat kerja karyawan KSP. Tat Twam Asi Denpasar.

Saran yang dapat diberikan penulis berdasarkan penelitian ini yang pertama saran secara teoritis, untuk meningkatkan semangat kerja karyawan hal yang harus diperhatikan adalah kompensasi finansial, lingkungan kerja non fisik, dan komitmen organisasional.

Saran untuk KSP. Tat Twam Asi Denpasar untuk dapat meningkatkan semangat kerja dari karyawannya secara keseluruhan sebaiknya perusahaan lebih memperhatikan indikator-indikator yang nilai rata-ratanya berada dibawah nilai rata-rata variabel seperti pada variabel kompensasi dengan indikator tunjangan dan gaji, pada lingkungan kerja non fisik dengan seluruh indikator yang ada, serta komitmen organisasional dengan indikator perasaan sulit meninggalkan organisasi, karyawan memiliki kewajiban dan tanggung jawab untuk tetap bertahan dalam organisasi serta berpindah ke organisasi lain sangatlah tidak etis. Karena hal tersebut dapat meningkatkan semangat kerja dari karyawan itu sendiri.

Bagi peneliti selanjutnya diharapkan untuk melakukan penelitian dengan cakupan yang lebih luas, menambah variabel-variabel lain diluar penelitian ini serta diharapkan mampu menambah referensi terhadap variabel yang akan diteliti.

\section{REFERENSI}

Abdul Karim, N. H \& Mohammad Noor, N. H. N. (2006).Evaluating the Psychometric Properties of Allen and Meyer's OC Scale: A Cross Cultural Application Among Malaysian. Academic Librarians' Malaysian Journal of Library and Information Science, Vol 11(1), pp: 89-101.

Adrian, T., Buboltz, W. C. \& Winkelspecht, C. S.(2004). Job characteristics and personality as predictors of job satisfaction. Journal of Organizational Analysis, Vol 12 (2), pp: 205-219.

Ahmad dan Suryana, I. (2009). Pengujian Aktivitas Ekstrak Daun Sirih (Piper betle Linn) Secara In Vitro IPB Bogor. Buletin Littro, Vol 20(1), 92 - 98. 
Allen and Meyer. (2013). The Measurement and Antecedents of Affective, Contintinuance and NormativeCommitment to Organitazion. PT Elex Media Komputindo: Jakarta.

Anis Rahmawati. (2009). Efisiensi Filter Pasir-Zeolit dan Filter Pasir-Arang Tempurung Kelapa dalam Rangkaian Unit Pengolahan Air untuk Mengurangi Kandungan Mangan dari Dalam Air. Seminar Internasional Hasil Penelitian Eksakta 3 Surakarta.

Anisa M. V. (2015). The Effect of Exercises on Primary Dysmenorrhea. Journal Mayority. Vol 4(2), pp: 120-134.

Azeem S. M. (2010). Job satisfaction and organizati onal commitment among employees in the sultanate of Oman. Journal of Psychology, Vol.1(1), pp: 295-299.

Baron R. A., Greenberg J. (1990). Behavior in Oganizations Understanding and managing the human side of work (3rd ed.). Boston : Allyn\& Bacon.

Bechtold, W. A., M. E. Mielke, dan S.J. Zarnoch. (2002). Crown Position and light exposure Classification - An Alternative to Field - Assigned Crown Class. Journal of Applied forestry, Vol. 20(4), pp: 154-160.

Carnahan Seth, Agarwal, Campbell, dan Franco. (2010). The Effect Of Firm Performance: Is There Any Relationship. Journal of Business \& Economics Research, Vol. 7(11), pp: 34-67.

Coryanata, Isma. (2004). Pelimpahan Wewenang dan Komitmen Organisasi Dalam Hubungan Antara Partisipasi Penyusunan Anggaran Dan Kinerja Manajerial. Simposium Nasional Akuntansi VII.

DeStefano, T.J., Henry, C., Megan G., dan Thomas P. (2006). The Relationship between Work Environment Factors and Job Satisfaction Among Rural Behavioral Health Professionals. Journal of Rural Community Psycology, Vol. 1(2), pp: 123-127.

Diana, Putu Gidion Alfa dan Made Subudi, (2013). Pengaruh Komunikasi dan Kompensasi terhadap Kinerja Karyawan yang Dimediasi oleh Semangat Kerja Karyawan. Jurnal Bisnis dan Kewirausahaan, Vol. 2(1), pp: 98122.

Duchon, D., and Plowman, D.A. (2005). Nurturing spirit at work: impact on work unit performance, Leadership Quarterly, Vol. 16, pp. 807-33.

Febriani, Ni Luh Mita dan Made Subudi, (2015). Pengaruh Kepemimpinan Transformasional, Budaya Organisasi dan Kompensasi Finansial pada Kinerja Karyawan. E- Jurnal Manajemen Universitas Udayana, Vol.4(5), pp: 43-51. 
I Gede Widya Darmawan, Pengaruh Kompensasi Finansial.....

Ghozali, Imam. (2009). "Aplikasi Analisis Multivariate dengan Program SPSS ".Semarang : UNDIP.

Hasibuan, Malayu S.P. (2016).Manajemen Sumber Daya Manusia (Edisi Revisi). PT Bumi Aksara: Jakarta.

Husein, Umar. (2010). Riset pemasaran dan bisnis. Gramedia Pustaka Utama: Jakarta.

Isma Coryanata. (2004). Pelimpahan Wewenang Dan Komitmen Organisasi Dalam Hubungan Antara Partisipasi Penyusunan Anggaran Dan Kinerja Manajeriall. Disampaikan Pada Simposium Nasional Akuntansi (Sna) Vii. Denpasar, 2-3 Desember 2004

Jane Nelima Wekesa dan Silas Nyaroo. M.a. (2013). Effect of Compensation on Performance of Public Secondary School Teachers in Eldoret Municipality Kenya. International Journal of Scientific and Research Publications. 3(6): h:1-4.

Kathleen dan Harold, (2010). Executive Compensation as a Moderator of the Innovation - Performance Relationship. Journal of Business and Management. 16(1)

Kinjerski, Val dan Berna J. Skrypnek. (2006). Creating Organization Condition That Foster Employee Spirit at Work. Leadership and Organization Development Journal, Vol 27 No 4.. pp: 280-295.

Leighton JA, Shen B, Baron TH, Adler DG, Davila R, Egan JV, et al. ASGE. (2006). guideline: endoscopy in the diagnosis and treatment of inflammatory bowel disease. Gastrointest Endosc. Apr 2006;63(4):55865 .

Lelyana, R. (2008). Pengaruh Kopi Terhadap Kadar Asam Urat DarahStudi Eksperimen Pada Tikus Rattus Norwegicus Galur Wistar. Tesis Program Pascasarjana Magister Ilmu BiomedikUniversitas Diponegoro Semarang.

Luthans, Fred. (2012). Organizational Behavior, an Evidence-Based Approach. New York: The McGrow, Hill Companies.

MacRobert M, Schmele J.A., and Henson R. (2008). An analysis of job morale factors of community health nurses who report a low turnover rate. The research. Internasional Journal Oklahoma City, Vol. 1(4), pp:4257.

Mardiana. (2005). Manajemen Produksi. Penerbit Badan Penerbit IPWI: Jakarta.

May, D. R., Gilson, R. L., \& Harter, L. M. (2004). The psychological conditions of meaningfullness, safety and availability and the engagement of the 
human spirit at work. Journal of occupational and organizational psychology, Vol. 7(1), pp: 11-37.

Murty, Windy Aprilia dan Gunasti Hudiwinarsih. (2012). Pengaruh Kompensasi, Motivasi dan Komitmen Organisasi Terhadap Kinerja Karyawan bagian Akuntansi (Studi Kasus Pada Perusahaan manufaktur di Surabaya). The Indonesian Accounting Review. Vol. 2(2), pp: 215-228.

Noton, (2011). Developing and Validating Trust Measures for e-Commerce Mcknight et al, (2002).

Philip, Stacey dan Ling Tsai. (2010). The Impact of job Mobility, Hourly Compensation, \& Work Hours on Job Satisfaction. Institute For Reseach In Training \& Development, Vol. 9(2), pp: 234-241.

Pravasta, I.N.G. dan Desak Ketut Sintaasih. (2014). Kompensasi Dan Motivasi: Pengaruhnya Terhadap Semangat Kerja Karyawan PT. Tjendana Mandra Sakti Denpasar. E- Jurnal Manajemen Universitas Udayana, Vol 3(5), hal: 23-34.

Purnamandari, Ni Wayan Quiena dan I Wayan Suana, (2014). Analisis Faktor Motivasi, Kepemimpinan, Lingkungan Kerja, Komunikasi, Penempatan Karyawan, dan Kompensasi yang Mempengaruhi Semangat Kerja Karyawan Hotel Bali Hyatt Sanur Bali. E- Jurnal Manajemen Universitas Udayana, Vol. 3 (8), hal: 5-11.

Richard L. Solomon, (1980), The Opponent-Process Theory of Acquired Motivation : The Cost of Pleasure and the Benefits of Pain, University of Pensilvania

Rimawathi. (2008). Analisis Faktor Penentu Semangat dan Kegairahan Kerja Karyawan di Kantor Dinas pendidikan Nasional Propinsi Bali. Tesis Universitas Udayana.

Roof, Richard A. (2014). The Association of Individual Spirituality on Employee Engagement: The Spirit at Work, 585-599

Sari, Areilistia Dewi, (2014). Pengaruh Pengawasan, Kompensasi dan Lingkungan Kerja Non Fisik terhadap Semangat Kerja Karyawan di PT. Hero Supermarket Tbk, Tbk. Cabang Superdome Semarang. Jurnal Universitas Pandanaran, Semarang.

Sebastian Buhail, Elena Cottini dan Neils Westergad Nielsen. (2008). The impact of workplace condition on firm performance, Tinbergen Institute Discussion Paper. 077(3):h :1-29.

Sedarmayanti, (2013), Manajemen Sumber Daya Manusia, Bandung: Refika Aditama. 
I Gede Widya Darmawan, Pengaruh Kompensasi Finansial.....

Sedarmayanti. (2011). Manajemen Sumber Daya Manusia, Reformasi Birokrasi dan Manajemen Pegawai Negeri Sipil (cetakan kelima). Bandung : PT Refika Aditama

Simamora, Henry. (2006). Manajemen Sumber Daya Manusia (Cetakan kedua). STIE TKPN: Yogyakarta.

Sopiah. (2013). The Effect Of Compensation Toward Job Satisfaction And Job Performance Of Outsourching Employees Of Syariah Bank. International Journal Of learning And Development. 3(2):h:1-15

Srivastava, (2008). Effect of Perceived Work Environment on Employees' Job Behaviour and Organizational Effectiveness. Journal of the Indian Academy of Applied Psychology. 34(1):h:47-55

Sugiyono. (2010). Metode Penelitian Pendidikan Pendekatan Kuantitatif, kualitatif, dan $R \& D$. Bandung: Alfabeta

Susilo, Martoyo.(2012). Manajemen Sumber Daya Manusia. Erlangga : Jakarta.

Suyana Utama, Made. (2009). Buku ajar Aplikasi Analisis Kuantitatif. Fakultas Ekonomi Universitas Udayana: Denpasar.

Triyana, I Nyoman Yudi dan I Made Artha Wibawa, (2014). Pengaruh Gaya Kepemimpinan Transformasional, Insentif Finansial Dan Komitmen Organisasional Terhadap Semangat Kerja Karyawan The Stones Legian Bali Hotel. E- Jurnal Manajemen Universitas Udayana, Vol. 3(11), hal:10-17.

Ursa Majorsy. (2007). Kepuasan Kerja, Semangat Kerja, dan Komitmen Organisasional pada Staf Pengajar Universitas Gunadarma. Jurnal Psikologi, Vol. 1(1), hal. 12-18.

Varlie, Denny, (2012), Hubungan Motivasi Kerja Dengan Kinerja Tenaga Perpustakaan, Studi Korelasi Tentang Hubungan Motivasi Kerja dengan Kinerja Tenaga Perpustakaan Pada Perpustakaan CISRAL, http://pustaka.unpad.ac.id

Vroom, Victor H. (1964). Work and Motivation. John Willey \& Son: New York Inc.

Yasa, I Ketut Manik Swardika dan I Made Artha Wibawa, (2015). Pengaruh Kompensasi Finansial, Komunikasi dan Lingkungan Kerja Fisik terhadap Semangat Kerja Karyawan. E- Jurnal Manajemen Universitas Udayana, Vol. 4(3), hal: 23-25. 